\title{
Danske folkebiblioteker under besættelsen
}

\section{En personlig beretning}

\author{
Af Preben Kirkegaard
}

Det historiske tidsrum, der skal beskrives, er 1940-45, og vi kan yderligere præcisere det fra 9. april 1940 til 5. maj 1945. Da jeg er blevet bedt om at redegøre for mine personlige erfaringer fra folkebiblioteksarbejdet, ja, så lader stedet sig præcist lokalisere til Ărhus Folkebibliotek, som tillige var centralbibliotek og derfor betjente et stort landdistrikt med mange sognebiblioteker, for at være helt nøjagtig havde vi 66 selvstændige sognebiblioteker, og hertil kommer et antal udlånssteder, som vel bringer tallet op på hen ved 100 enheder. Ărhus havde 90.898 indbyggere og i biblioteket var indskrevet 14.949 voksne lånere, som lånte 361.172 bøger $\mathrm{i}$ løbet af det første krigsår, hvor budgettet var på $154.140 \mathrm{kr}$. og bogbestanden $49.147 \mathrm{bd}$. Da børne- og skolebiblioteker i disse år var selvstændige administrative enheder, udelukker jeg omtalen af deres arbejde.

Jeg skal skåne Dem for flere statistiske oplysninger, men jeg finder det relevant gennem et par streger at skitsere de størrelsesforhold, hvorunder vi arbejdede.

Det materiale, vi arbejdede med, bogsamlingen, var som nævnt knap nok 50.000 bd., som ned til de mindste detaljer var præget af én mands

Preben Kirkegaard, tidl. rektor ved Danmarks Biblioteksskole; Vemmetofte Kloster pr. Fakse.

Foredrag i Dansk Bibliotekshistorisk Selskab den 5. maj 1995 på Danmarks Biblioteksskole. 
ildhu og kompetence til at opbygge en udvalgt samling af den på dansk foreliggende klassiske litteratur (med stort L) og den aktuelle problemprægede litteratur, som afspejlede de sociale tilstande og ideologiske strømninger - der var meget lidt plads til det, man i vore dage kalder triviallitteraturen; af f.eks. Morten Korch, som skrev en mængde lavfolkelige romaner, havde vi i Ărhus kun hans Fynske Fortellinger i 2 bd.

Den faglitterære samling var opbygget med en tilsvarende kompetence og seriøsitet overfor opgaven.

Manden - ja, jeg vil sige mesteren - for skabelsen af dette bibliotek var overbibliotekar Carl Thomsen, der i 1933 var blevet chef for det nye folkebibliotek i Ărhus, som skulle bygges op helt fra grunden - der var 0 bøger og en halvfærdig nybygning, da han tiltrådte. Jeg selv blev elev i 1934 og efter biblioteksskolen fast ansat i 1936, og er derfor dybt præget af min læremester Carl Thomsen, hvis holdning overfor vor opgave han har formuleret i et foredrag, hvorfra jeg citerer: 'Den bibliotekar, for hvem intet spørgsmål er for ubetydeligt, ingen søgen ligegyldig, ingen fejlbedømmelse irriterende, bidrager mere end den mest fremragende organisator til, at biblioteket bliver det fristed for menigmand, der er forudsætningen for, at det også kan blive hans universitet," og jeg citerer også Hvenegaard Lassens særdeles rammende karakteristik af Carl Thomsen i det festskrift, som udkom ved Carl Thomsens afgang som stadsbibliotekar for København i 1962: "Gennem hele Carl Thomsens biblioteksliv går som en rød tråd en bevidst bestræbelse for at skabe forbindelse mellem folkebibliotekerne og alle andre grene af folkeoplysende arbejde. I den retning har han udført mere end nogen anden biblioteksmand. Han er aldrig blevet træt af at fremhæve, at bibliotekarerne stadig må være opmærksomme på det oplysende arbejde, der udføres udenfor bibliotekerne og lade sig inspirere af det."

Jeg har nu skitseret bibliotekets karakter og den ånd, som udgik fra chefen og som vi menige bibliotekarer søgte at leve op til.Jeg har gjort det for at angive den karat, som prægede bibliotekararbejdet, og niveauet af den bogsamling vi forvaltede - $\mathrm{i}$ det håb at de unge nu vil kunne forstå, at vi også på den baggrund oplevede besættelsen den 9. april som en katastrofe, der fremkaldte en dyb angst for fremtiden og et lidenska- 
beligt had mod besættelsesmagten. De tyske tropper sejrede og sejrede, og de nazistiske visioner om et Neuropa, hvor Danmark skulle være en del af det, de kaldte "Nordmark", føltes som en skræmmende politisk mulighed.

Men, men dagens arbejde skulle jo gennemføres - og her var der opmuntring og inspiration at hente.

Det regnede ned over os med restriktioner, som blev påbudt og som skulle gennemføres, lige fra mørklægningsforanstaltninger, nedsættelse af el- og varmeforbrug, trafikproblemer osv. osv., ja disse ting lod sig jo løse, de var blot besværlige. Hvad der ikke var besværligt, men en kæmpeudfordring til bibliotekerne og deres medarbejdere var håndteringen af den enorme vækst $i$ lånertal og udlån. Selvom jeg tidligere har lovet Dem, at De ikke vil blive belemret med mere statistik, så vil jeg alligevel illustrere arbejdsmængden med to tal: I løbet af det første krigsår fik vi i Ărhus 2.253 lånere mere og udlånet steg med 81.896 bind. Så vidt jeg husker, betød det ikke, at der blev normeret flere stillinger; men nok at vi fik lidt flere timelønnede medhjælpere eller bogopsættere.

Som tidligere næunt var Carl Thomsen den store forkæmper for at skabe samarbejde med andre oplysningsformer og samtidig udvikle pædagogiske initiativer til direkte anvendelse i det bibliotekariske arbejde med og for bogen. Det enkleste bibliotekspædagogiske instrument er vel den annoterede katalog, og jeg mener, at det var fra Ârhus Folkebibliotek initiativet udgik til udarbejdelsen af snesevis af de små Las med Plan-publikationer, i et format som vistnok stadig anvendes. De fleste Las med Plan indeholdt, så vidt jeg husker, "bibliotekarisk udformede" introduktioner til et forfatterskab, men det kunne også dreje sig om emner som "Håndarbejde", "Musiklitteratur" m.m.

Biblioteksbygningen i Ărhus var kun ca. 5 år gammel, da besættelsen kom, og den var dels et smukt stykke arkitektur, og dels svarede lokaleindretningen $\mathrm{i}$ stort omfang til Carl Thomsens visioner om bibliotekernes samarbejde med andre folkeoplysningsorganisationer og -institutioner.

I bygningens 2. etage var der en halv snes pænt indrettede studiekredsværelser, beregnet til ca. 15-20 personer, et større auditorieagtigt 
lokale til et halvthundrede, samt en stor foredragssal, hvor allehånde foreninger kunne afholde møder - der var kun ét forbud knyttet til udlejningen - ingen dans og kortspil, men rygning var tilladt! Denne sal blev i hvert fald de forste år af besættelsestiden flittigt brugt til "bibliotekspædagogiske" formål, idet vi arrangerede "litterære aftener", hvor nu og da en århusiansk Ping holdt foredrag, men i de fleste tilfælde var det en af vore egne, fortravlede bibliotekarer, der forelagde sine "læsefrugter". Jeg erindrer selv at have præsenteret forfattere som Hans Povlsen, Âge Dons, Aage Madelung og nok lidt flere - de store navne som Jakob Knudsen, Henrik Pontoppidan, J.P. Jacobsen og Herman Bang dem "fortolkede".jeg i omegnens forsamlingshuse, når sognebibliotekerne holdt generalforsamling med kaffebord!

Lige et par ord om studiekredsbevægelsen, som fra slutningen af 30erne voksede sig stor - især var det AOF, der organiserede arbejdet. Det var en udvikling, som vi fra bibliotekernes side støttede meget stærkt og i 1938 oprettede man Studiekredscentralen, som forvaltedes af Statsbiblioteket i Ârhus. Folkebibliotekets mange studiekredsværelser blev stærkt anvendt - og her blev i 1940 den første århusianske studiekreds i litteratur gennemført. Den blev en succes og jeg havde i vinteren 1944 ikke færre end 3 studiekredse i "moderne litteratur" og "dansk litteratur".

Som nævnt løste vi også centralbiblioteksopgaver for hen ved 100 sognebiblioteker og filialer, hvoraf en stor del fik faste besøg 2-3 gange årligt af bogbilen, ligesom vi ofte deltog i bogvalgsmøder ude i sognene. På det trafikale område måtte vi overvinde mange svære vanskeligheder, men bogbilen fik installeret en gasgenerator, og vor særdeles effektive vognmand tiltuskede sig dæk og slanger, så vi gennemførte i en lang periode opretholdelsen af denne vigtige funktion.

Da den offentlige trafik var stærkt nedskåret, så betød det, at afholdelse af bogvalgsmøder, som vi anså for livsvigtige for biblioteksarbejdet $\mathrm{i}$ landdistrikterne, kunne være særdeles krævende. De kunne medføre overnatninger eller f.eks. at Carl Thomsen og jeg engang måtte leje en tandemcykel og køre fra Århus til Rønde retur - der var mange bakker på det vejstykke, men vi gennemførte vor opgave. 
I forbindelse med denne korte omtale af oplandsarbejdet, der efterhånden udviklede sig til et netværk af nære personlige kontakter med sognebibliotekarerne, der oftest var stedets lærer eller i nogle tilfælde sognepræsten, vil jeg gerne fremføre, ganske, ganske kort, nogle bemærkninger om karakteren af det illegale arbejde, som jeg i nært samarbejde med vor leder af katalogafdelingen Mine Islev var indblandet $i$, og som jeg ved også blev udført af i hvert fald to andre oplandsbibliotekarer, Oluf Abitz i Vejle og Gustav Auring i Silkeborg - vi havde nogle gange direkte samarbejde om svære illegale opgaver.Vi fire var tilknyttet den af Frode Jakobsen ledede modstandsbevægelse kaldet "Ringen", der i begyndelsen hed "Studieringen", som udgav et løbende illegalt blad, men som efterhånden udviklede sig til også at organisere andre aktiviteter indenfor modstandsarbejdet.

Jeg kan ikke modstå fristelsen til her at citere en fremtrædende og "rigtig" modstandsmand, som deltog i nogle af de hårdeste og vanskeligste aktioner: våbenmodtagelserne. I Toldstrups tjeneste er titlen på Jørgen Hesseldahls skildring, udkommet til 50 årsdagen for befrielsen. Han var en kort tid bogopsætter på folkebiblioteket i Ărhus og han skriver "men det var fra bibliotekets næstkommanderende P. Kirkegaard, jeg i denne situation fik hjælp - han gav mig en liste over de sognebibliotekarer, han forventede ville viderebringe vore blade."

Bogbilen medførte altså andet end biblioteksbøger - jeg var dog aldrig "våbenførende".

Jeg har måske gennem det foregående tegnet en "lykkelig arbejdssituation" og det mener jeg også, at der faktisk var - vi mødte som en kulturinstitution en enorm stor udfordring og vi fik næsten uforstyrret fred til at yde vort bedste. Den angst, vi følte den 9. april, forlod os vel aldrig helt, for næsten hele verden lå i krig; men vi må indrømme, at tyskerne kun forvoldte os lidt skade i vort arbejde. Der, hvor vi mødte de fleste problemer, var fra de danske nazister, som, hvor latterlige og foragtelige de end var, kunne repræsentere en potentiel politisk fare. I deres dagblad Fadrelandet kunne man finde stærke angreb på enkelte bibliotekarer eller på biblioteksvæsenet, der karakteriseredes som et farligt socialistisk element, hvis virke ødelagde det danske samfund. Hvad 


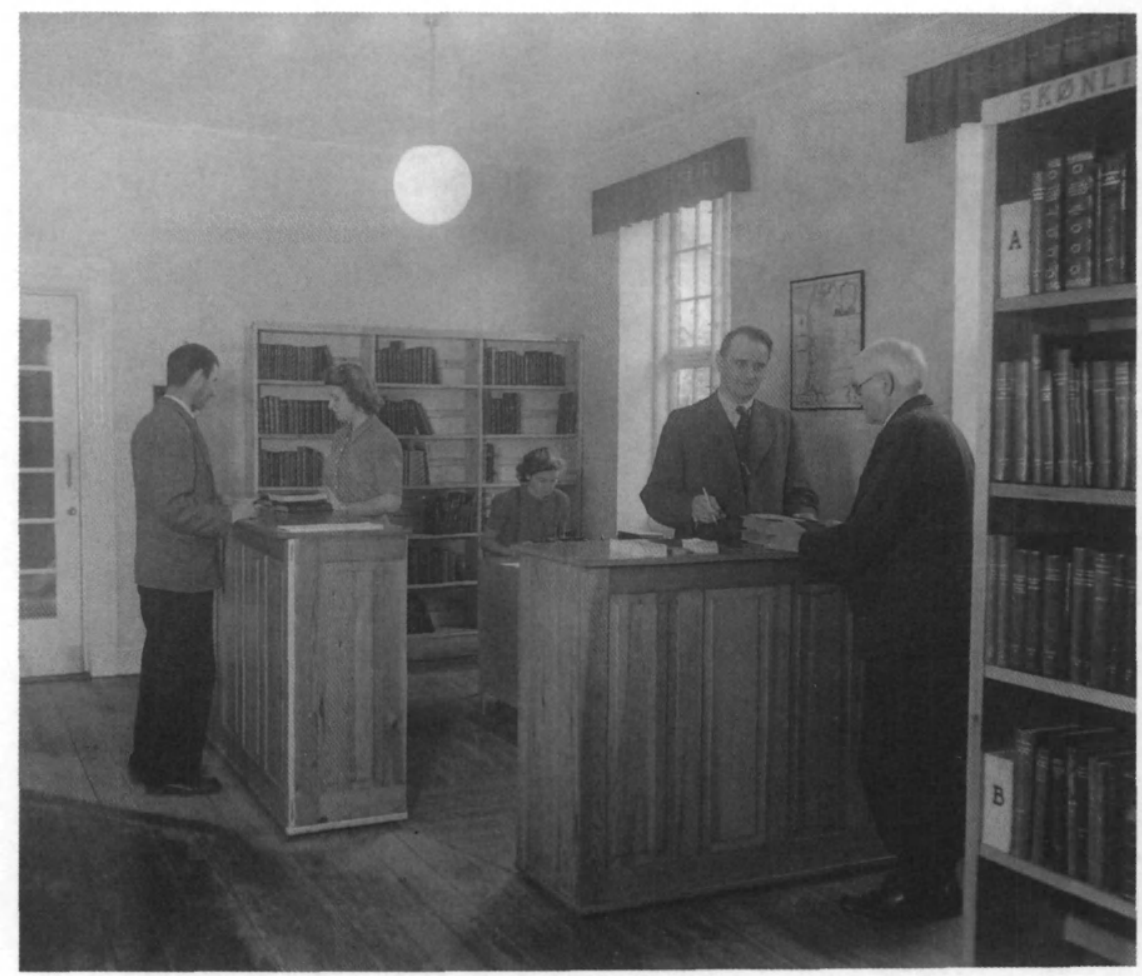

Preben Kirkegaard $i$ udlånet på Holstebro Centralbibliotek. Kirkegaard var overbibliotekar $i$ Holstebro 1945-46. Danmarks Biblioteksskole, Bibliotekshistorisk Billedsamling.

angår forholdene i Ârhus kan jeg eksempelvis citere fra National Socialisten den 19. marts 1942:

"Hr.Thomsen er nemlig "Kultur"-Bolchevik. Han var Medarbejder ved det berygtede Smudsblad "Kulturkampen" og Repræsentant for samme "Kultur"-kreds i Aarhus og Omegn. Og han er altsaa endnu Leder af det kulturelle Arbejde i Aarhus indenfor Biblioteksvæsenet.

Hans nære Ven og Medarbejder, Biblioteksassistent Preben Kirkegaard er en Herre, som vi skal kigge lidt paa ved anden Lejlighed. Han udfolder for Tiden en rig Virksomhed indenfor "Ungdomssamvirket"."

Mange angreb i den nazistiske presse blev produceret af en bibliotekar Arne Hansen, som havde været elev i Centralbiblioteket i Nykøbing Falster, men ellers ikke haft ansættelse i noget folkebibliotek efter sin eksamen fra Statens Biblioteksskole. Han havde gennemgået en tysk 
førerskole og virkede derefter som journalist ved den nazistiske presse. Hans læremester i Nykøbing Falster, overbibliotekar Knud Hansen, var intet mindre end sysselleder i DNSAP's afdeling på Falster og han var en ikke ufarlig mand. Fra ham udgik f.eks. en hård kampagne for udrensninger $\mathrm{i}$ folkebibliotekernes bogbestand af jødiske forfattere, af kommunistiske bøger og af nyere engelsk/amerikansk litteratur. Han forlangte også i forskellige nazistiske publikationer, at den Falleskatalog for storre Kobstadbiblioteker, som var et af folkebibliotekernes vigtigste instrumenter i lånerbetjeningen, skulle erstattes af en ny og udrenset udgave. Fra bibliotekernes side valgte man at undlade et genoptryk af den tidligt udsolgte fælleskatalog med ca. 3600 titler, og man måtte således savne et vigtigt instrument. Knud Hansen rasede og prøvede forgæeves med loven om kommunisterne $\mathrm{i}$ hånd $\mathrm{og}$ henvisninger til officielle dokumenter vedrørende besættelsen og Anti-Kominternpagten at fremtvinge sine forslag. Han blev umiddelbart efter kapitulationen afskediget af biblioteksbestyrelsen i Nykøbing - og endte, så vidt jeg ved, som bestyrer af en tobaksforretning på Vesterbro.

Den eneste direkte tyske indblanding i biblioteksarbejdet var en henvendelse af 12. november 1942 bilagt en liste over nogle få bøger og beslaglagte pjecer, som via justits- og undervisningsministeriet blev udsendt af Statens Bibliotekstilsyn, underskrevet af Thomas Døssing, som meddelte, at de nævnte bøger ikke måtte udlånes eller fremlægges, da de ville kunne skade landets interesser i forhold til udlandet, og at udlån af tyskfjendtlige bøger i øvrigt var strafbart. Listen omfattede følgende:

$\begin{array}{ll}\text { Bilag 1 } & \\ \text { Alexander: } & \text { Der Mythus Hitler } \\ \text { Heiden, K.: } & \text { Hitler } \\ \text { Ludecke: } & \text { I knew Hitler } \\ \text { Olden, R.: } & \text { Hitler } \\ \text { Bang: } & \text { Hurra og Halleluja } \\ \text { Rathenau, W.: } & \text { Det nye Tyskland } \\ \text { Ehrlich, K.: } & \text { Fra Berth til Hitler } \\ \text { Stockert: } & \text { Tyskland og Sovjet } \\ \text { W.reshner: } & \text { Rigsdagsbranden }\end{array}$


Mürer:

Dimitroff, Georgi:

Lenin, V.L.:

Nexø, Martin Andersen:

Blædet, Nic.:

Frisch, Hartvig:

Reed, Douglas:

Langhoff, Wolfgang:

Stender-Petersen:
Det nye Tyskland

Georgi Dimitroffs Liv og Kamp for Folkefronten. Artikler og taler.

Staten og Revolutionen

To Verdener. Tanker og Indtryk fra en Ruslandsrejse Storpolitik 1938

Pest over Europa. Bolchevisme-Fascisme-Nazisme

Galskabens Kavalkade. Grænseløs Skændsel

Et Aars Helvede (Skildring af en tysk Koncentrationslejr)

Revolutionære Profiler. Bidrag til den russiske

Revolutions Karakteriologi

Bilag 2

Preben Wench:

Den fulde Sandhed

21.01.1941

27.01.1941

Vilh. La Cour:

Om at sige Ja eller $\mathrm{Nej}$

05.02 .1941

Vilh. La Cour:

Pjece

Ord til os i Dag

04.02 .1941

08.04 .1941

Vilh. La Cour:

Pjece

Vilh. La Cour:

Pjece

Vor Neutralitet

15.10.1941

Soya:

Bog

Kender De Graabonden

13.10.1941

Kaj Munk:

En gxst

09.10 .1941

19.09.1941

31.10 .1941

Poul Sørensen:

Digte

Niels Ebbesen

11.04.1942

Arbejdsfronten

April i Danmark

08.04.1942

15.07.1942

Nyt fra Dansk Samling

Nr. 11

11.07.1942

08.07.1941

Nr. 6, Arne Sørensen

19.07.1941

22.07.1941

Den første dato angiver beslaglæggelsens dato, medens den anden dato angiver datoen for det nummer i Statstidende, hvori kundgørelsen om beslaglæggelsen er optaget.

Rent praktisk gjorde vi i Ărhus det, som vist var almindeligt ved de fleste biblioteker, at vi flyttede de få anførte bøger i magasinet og fortsatte udlånet til pålidelige lånere.

Bibliotekstilsynets skrivelse virkede som en bombe - det vi havde frygtet: Censur, var det nu på vej? Nogle bibliotekarer - dog vist kun fă var dybt forargede over, at biblioteksdirektør Døssing ville lægge navn til indførelse af censur, men $i$ almindelighed erkendte man, at "samarbejdspolitikken" indebar, at også embedsmændene måtte gøre deres 
pligt, hvor meget det end kunne stride imod den personlige overbevisning.

Døssing var fra - næsten - alle sider anerkendt som den ledende danske biblioteksmand. Han var en jysk bondesøn, som var begyndt at studere teologi, men forlod studiet i 1906 for at blive assistent ved Det kgl. Bibliotek, og i 1908 fik han ansættelse som underbibliotekar ved Statsbiblioteket i Ărhus, hvorefter han i 1912 blev bibliotekar ved Statens Bogsamlingskomité for endelig i 1920 at blive biblioteksdirektør i henhold til den første lov om folkebiblioteker, i hvis tilblivelse han havde været meget aktiv. Han blev pioneren for hele den følgende biblioteksfaglige udvikling og var $i$ hele sin lange embedsperiode den visionære og ubestridte leder af folkebibliotekernes opbygning. Rent personligt var han en charmerende mand med et stort socialt engagement og hertil suveræn på en talerstol, hvorfra han klart docerede sine skarpe meninger. Han var derfor en skikkelse, som besættelsesmagten havde under observation, hvilket førte til at de i december 1942 forlangte, at det danske politi skulle arrestere ham og derpå overføre ham til tysk politi. Anklagen lød på (1) kommunistisk virksomhed, (2) antitysk propaganda og (3) opfordring til sabotage med den tyske værnemagt.

Efter at de tyske myndigheder havde behandlet sagen, blev han overført til en dansk domstol, som idømte ham 4 måneders hæfte, som imidlertid var udstået med varetægtsarresten. Da han ville vende tilbage til embedet, fik han fra justitsministeriet besked på, at han var interneret og under en slags husarrest i sit eget hjem. I 1944 flygtede han til Moskva, som havde anerkendt ham som minister og repræsentant for den danske frihedsbevægelse, og efter kapitulationen blev han af den nye danske regering anerkendt som kgl. gesandt i USSR, og her arbejdede han til sin død den 18. april 1947 på at genoprette ældgamle og gode forbindelser med det store russiske rige.

Det blev en eventyrlig karriere for en dansk bibliotekar, der har sit navn indskrevet på en førsteplads i vor bibliotekshistorie.

Jeg vil give en personlig beretning om de to danske bibliotekarer, Kinch og Schøtler Nielsen, som mistede livet i tysk fangenskab. Deres minde blev markeret ved, at mange danske kolleger stiftede "Kinch og 
Schøtler Nielsens mindefond til støtte for bibliotekarers videreuddannelse".

De begge var ansat på Århus folkebibliotek, Kinch fra 1938 og Schøtler Nielsen fra 1943.

Det var Schøtler Nielsens første ansættelse som bibliotekar, han havde i et par år studeret historie og latin ved Ărhus Universitet inden elevtiden i Randers og biblioteksskolen i 1943. I løbet af de fầ måneder han arbejdede i Ărhus, lærte vi ham at kende som en særdeles intelligent, charmerende og livlig ung mand, som man spåede en stor karriere indenfor biblioteksvæsenet.

Det virkede som et chok, da vi fik meddelelsen om hans arrestation den 6. juni 1944 under en Gestaporazzia i ejendomskomplekset "Klintegården" (som var den lokalitet, hvor Tage Skou-Hansens roman De nogne trcer udspilles). Han var her i færd med at hjælpe en kendt fagforeningsmand med at producere Ârhus Ekko - det illegale kommunistiske lokalblad. De blev begge arresteret og den 5. oktober blev Schøtler Nielsen deporteret til Neuengamme, hvor han omkom den 19. december 1944. Jeg har ikke kunnet fremskaffe flere oplysninger end disse få data, men vil slutte af med et citat fra overbibliotekar Gertrud Glahns lille nekrolog i Bogens Verden: "De, der lærte ham at kende, vil aldrig glemme ham, men tænke på ham i dyb taknemlighed."

Om Christian Kinch vil jeg derimod kunne fortælle en hel del, idet vi var venner, og jeg var delvis indblandet $\mathrm{i}$ den sag, som bevirkede hans fængsling den 30. august 1944.

Forhistorien er, at faldskærmsledelsen i København havde besluttet at etablere en direkte radioforbindelse fra Jylland til England, og man sendte civilingeniør A.Z. Gjødrik-Andersen af sted med det nødvendige sendeudstyr. Han fik forbindelse med ingeniør Leo Sørensen i Ărhus og skulle nu til at opbygge et net af sendesteder. Det er den overordnede forhistorie.

En dag fik jeg en henvendelse fra en omegnslæge, som spurgte om jeg ville stille min bolig til rådighed for en telegrafist, som skulle sende til England. Det blev aftalt, at jeg inden min stillingtagen skulle møde den fremmede mand, idet han den næste dag skulle sætte sig ind på fol- 


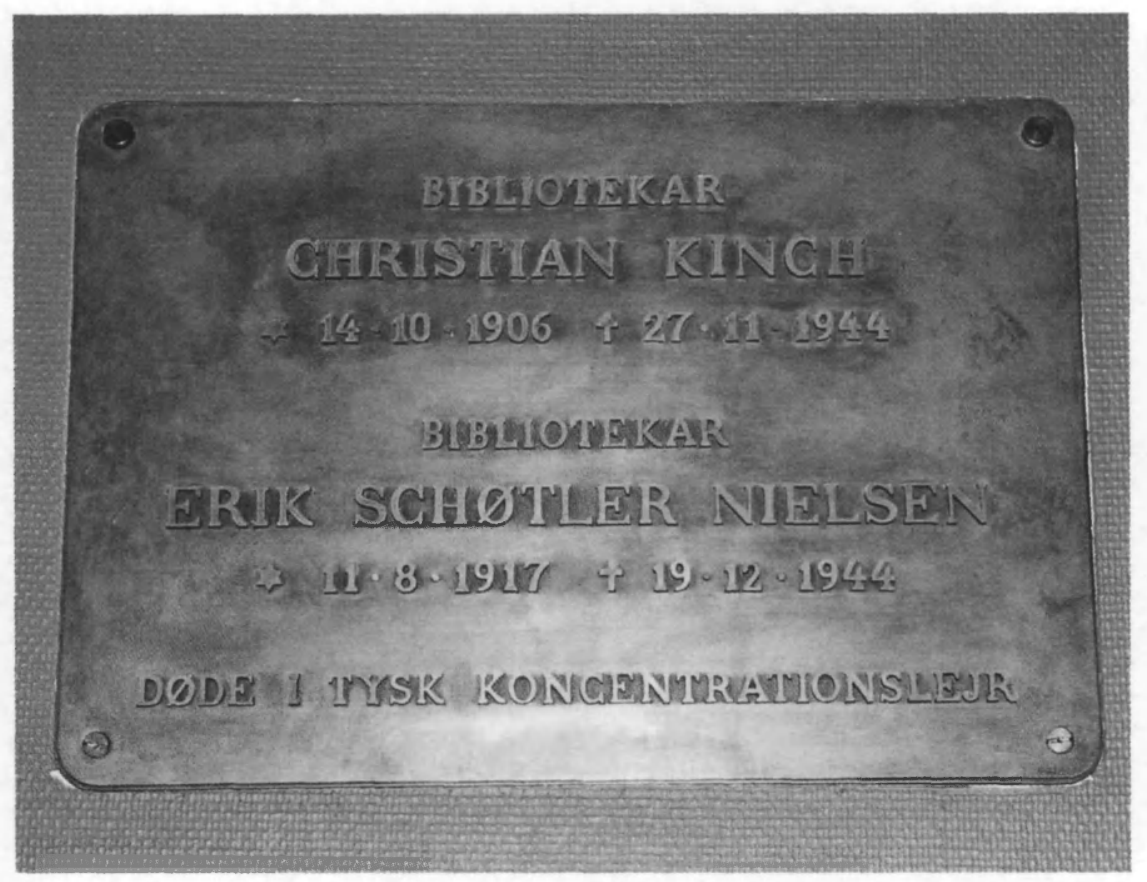

Mindeplade for bibliotekarerne Christian Kinch og Erik Sihotler Nielsen, som omkom i tysk koncentrationslejr i 1944.

kebibliotekets læsesal ved det 3. bord, klokken det eller det, og sidde med, så vidt jeg husker, et bind af Traps Danmark.

Jeg havde nu fået meget at tænke på, og der blev holdt familieråd, for det var givet, at det ville blive særdeles farligt at indlade sig på at huse en sender. Man vidste, at Gestapo havde mange muligheder for at spore radiobølger, selvom sendetiden kun var kort. Efter mange og lange overvejelser besluttede jeg at gå ind på en aftale med manden, dersom han mødte op og jeg fik de nødvendige informationer. Den næste dag sad der en mig ubekendt mand på det aftalte sted og til den aftalte tid. Jeg iagttog ham meget nøje $i$ en rum tid, men hele mit instinkt for at bedømme mennesker alene på deres udseende sagde: Nej og atter nej. I det illegale arbejde lærte man at, og måtte man ofte, tage en lynhurtig beslutning, når man stod overfor et ukendt menneske - var han til at stole på? Det kunne være skæbnesvangert at tage fejl. Jeg trak mig 
tilbage, undlod at kontakte manden nærmere - selvfølgelig med en sort samvittighed. Den kan den dag i dag plage mig - jeg var bestemt ingen dristig helt.

Nogle få dage senere fik vi meddelelse om, at Christian Kinch den 30. august 1944 var blevet arresteret af Gestapo, som havde fanget radiotelegrafisten og $\mathrm{i}$ hans lommebog fundet navne og adresser på medlemmer af den gruppe, han var ved at danne i Ărhus. Af disse blev ingeniør Leo Sørensen og bibliotekar Chr. Kinch begge arresteret, og begge blev i oktober sendt til Neuengamme, hvor de begge døde og hvor også radiotelegrafisten Gjødrik-Andersen endte sit liv.

Chr. Kinchs hårde skæbne har optaget mig meget, dels var vi venner og dels fordi jeg beundrede hans store dygtighed som bibliotekar. Han var 7-8 år ældre end mig, han, som tilhørte en kendt slægt af præster, var begyndt at studere teologi ved Københavns Universitet, men af økonomiske grunde måtte han opgive det langvarige studium og gå over til bibliotekargerningen, som han havde stort talent for. Men han oplevede nogle skuffelser i sin bibliotekarkarriere og i Ărhus genoptog han de teologiske studier samtidig med, at han varetog sit biblioteksarbejde med stor omhu og dygtighed - der var for mig ingen tvivl om, at hans inderste ønske var at blive præst, der var noget uforløst $i$ hans sind.

Og så denne hårde skæbne, som jeg ofte tænker over. Jeg søgte $\mathrm{i}$ mange år at efterspore den til bunds og for 15-20 år siden fik jeg oplysninger om tragediens afslutning fra en mand, som havde levet tæet på ham i barakken i en udkommando i Versen bei Meppen. Kinch var blevet syg af lungebetændelse eller lignende under det hårde landbrugsarbejde i lejren, hans tilstand forværredes og kammeraterne tilskyndede ham til at blive hjemme i barakken, idet de forsikrede ham, at de nok skulle klare hans arbejde, så det kunne holdes skjult for fangevogterne, at han blev i køjen. Den dag blev der uventet gennemført kontrol af selve barakken, så han blev tvunget ud. I sin syge tilstand anklagede han nu sine stuekammerater for, at de havde forrådt ham, og nægtede at tale med dem. Det sidste døgn lå han ensom og sang salmer, indtil døden indtraf den 27. november 1944. I sandhed: en hård skæbne.

$\mathrm{Nu}$ da jeg er ved at afslutte min korte beretning om en epoke, hvor Helvedets kræfter søgte at tilkæmpe sig den diktatoriske magt over alt 
og alle, en epoke hvor en meget lille hær af krigere uden våben søgte at værne den gennem mange generationers nedarvede kulturskat og retsforvaltning, en epoke hvis vilkår og muligheder for liv og vækst blev afgørende for det enkelte individs adfærd, holdning og værdimål. $\mathrm{Nu}$ må jeg spørge mig selv om denne min beretning lyder troværdig i de bibliotekarstuderendes ører i 1995. Eller tænker de: dette er en meget gammel bibliotekars nostalgiske tanker.

For at prøve mig selv fandt jeg en lille bog frem Folkebibliotekerne $i$ Danmark, som blev udgivet i 1948 af Det danske Selskab og som jeg skrev godt et årstid efter krigens afslutning - og altså i en alder, der ikke var mærket synderligt af senilitet. Jeg vil derfor afslutte dagens tema med at citere mig selv - noget man ikke bør gøre - og anmode om, at denne min sammenfattende bedømmelse af biblioteksarbejdet måtte blive antaget som troværdig:

"Det, der kendetegner det folkelige biblioteksvæsen under krigen og besættelsen, er en vækst i arbejdet og en betydning uden lige. Da det danske folk saa sit frie folkelige kulturliv og sin demokratiske samfundsordning, der helt og udelt hvilede paa høje retsprincipper, truet med udslettelse af en overvældende voldsmagt, søgte man at ruste sig til politisk og aandelig modstand. En ganske tydelig linje førte hen til en fornyet og forøget dyrkelse af og interesse for landets historie, for samfundslivets grundproblemer og for hele vor nationale kultur. I denne trang til at besinde sig over for de ændrede forhold - en trang, som greb alle samfundslag - søgte man især til litteraturen og dermed til bibliotekerne.

Den første og største opgave, tiden efter besættelsen stiller folkebibliotekerne overfor, bestaar $i$ at fastholde det store publikum, som krigstidens forhold bragte ind i bibliotekerne. Allerede i løbet af det første aar gik udlaanstallene ned; men det er ganske naturligt, at en vis afspænding finder sted.

Det meget store antal benyttere, som bibliotekerne stadig har, vil man uden tvivl kunne knytte varigt til sig ved et intensivt arbejde med at genopbygge den opslidte bogbestand og ved at udvide bibliotekets ydeevne mest muligt. Det vil tillige blive bibliotekets opgave gennem forskellige former for pædagogisk virksomhed yderligere at samle og 
anspore laanernes interesse for tilegnelse af litteraturen eller for bogen som hjælpemiddel til faglig dygtiggørelse." 